\title{
MUSLIM POLITICS AND DEMOCRACY The Case of Indonesia
}

\author{
Olle Törnquist \\ The University of Oslo, Norway
}

\begin{abstract}
This article tries to scrutinize the complexity of dealing with the attempts at crafting democracy in Indonesia. It relates the issue of deploying religion among Muslim actors with the issue of state-market powerrelations. With regard to the failing attempts of democratization, the writer argues that the problem does not lie with religion and Islam as such, but with democratisation that has run aground for a number of reasons. The real challenge is to develop more independent means of political representation. In his opinion, quoting Demos' survey, the major task in the country at large is to build popularly rooted and representative civic-political organisations. He goes on to argue that while Muslim politics may promote measures against corruption, and neo-liberal actors may foster the rule of the laws they have shaped, both tendencies neglect independent popular representation to promote politically equal control of public affairs.
\end{abstract}

Keywords: Democracy, civil society, equal citizenship, public sphere, Muslim democrats.

\section{Introduction}

The most frequently asked question for me during the last few years is no doubt this: "you who work on problems of democracy in the country with the largest Muslim population in the world, Indonesia, tell us now: isn't it so that Islam is the epitome antithesis to democracy and human rights?" I am not an expert on Islam, but I know something of politics and democracy. The question is a good one, because the answer is not as obvious or as clear as one should care to think. 
That is to say, democracy is of course undermined if it is a God and this God's representatives who are to decide how society should be run and governed, and not the people on the basis of political equality and their own interpretation of the world. But first, this perception is not limited to Islam alone. It concerns all religions. Second, as of today the upholding of the full symbiosis between politics and religion is limited to a rather small number of movements, groups, and leaders - Tali-ban as Ameri-can. In the real world we rather primarily have to do with mixtures of liberal, illiberal, secular and religious politics. In short, there are degrees of hell. And even then, for instance, according to the World Value Survey, there is no major difference in the view on democracy amongst Muslims living in 'Muslim countries' and for example Christians living in Christian dominated areas. Maybe we overstate or confuse a number of 'selfevident' differences.

Beyond categorical questions and fundamentalist answers, the more interesting dilemmas and fruitful questions are, therefore, what issues that are deemed to be public in Muslim and other politics, and what citizens that are supposed to control these public affairs on the basis of political equality. In other words: what problems and issues of common concern are not handled publicly in Muslim and other politics but within the private sphere, on the market, within the family and/or by religious leaders? And what people are not granted full civic rights? For instance because they are women, belong to another religion, do not have one, or are simply so economically vulnerable that they can not claim their rights? These questions are subject to dispute around the world. There are many positions and no simple answers. Maybe, for instance, the two most powerful political tendencies in contemporary Indonesia which tend to be viewed as opposites - the neo-liberal (i.e. market-) and Muslim value based politics - have more in common than what is usually taken for granted, thus forming a democratically most dangerous unholy alliance.

\section{A Democratic Point of View}

To discuss the dilemmas, we may wish to spend somewhat less time than has become fashionable to examine exciting more or less extremist tendencies and struggles in Muslim politics that fit into the Western picture of 'the other', to allow instead for more knowledge of the democracy that is supposed to be affected, but which is often viewed as a black box. 
This is important, because democracy is not one-dimensional. It is true that its generally accepted aim is popular control of public affairs on the basis of political equality. But this in turn calls for a large number of promotional means or institutions with a reasonable performance, substance and geographical scope; institutions which all people must then also be reasonably able to promote and use. The specific shape of the institutions may of course be contextual. For instance, the electoral systems may vary. But all the instruments are supposed to generate, firstly, an impartial judicial system (including equal citizenship, justice and the rule of law) and a number of civic, political and other human rights; secondly, direct and representative mechanisms for politically equal government and administration of public affairs; and thirdly, direct civic engagement by way of civil society (including media, culture, academia and associational life). ${ }^{1}$

1 While the International Handbook of Democracy Assessments by Professor David Beetham et. Al. (IDEA 2002) for instance, list some 85 institutions to generate democracy, the number has been boiled down to about half in Demos' (The Indonesian Centre for Democracy and Human Rights Studies) National Survey. (Priyono et.al. 2007 and Törnquist 2006). This is Demos' list of the outcomes that must be promoted by contextual rights and institutions to thus generate and sustain meaningful democracy: (1) Citizenship, Law and Rights: Equal citizenship, The rights of minorities, migrants and refugees, Reconciliation of horizontal conflicts, Government support and respect for international law and UN human rights treaties, Subordination of the government and public officials to the rule of law, Equal and secure access to justice, The integrity and independence of the judiciary, Freedom from physical violence and the fear of Freedom of speech, assembly and organisation, Freedom to carry out trade union activity, Freedom of religion and belief, Freedom of language and culture, Gender equality and emancipation, The rights of children, The right to employment, social security and other basic needs, The right to basic education, including citizen's rights and duties, Good corporate governance and business regulations in the public interest. (2) Representative and accountable government: Free and fair general elections at central, regional, and local levels, Free and fair separate elections of e.g. governors, mayors, Reflection of vital issues and interests among people by political parties, Abstention from abusing religious or ethnic sentiments, symbols and doctrines by political parties, Independence of money politics and powerful vested interests by political parties, Membership-based control of parties, and responsiveness and accountability of parties to their constituencies, Parties ability to form and run government, The transparency and accountability of elected government, at all levels, The transparency and accountability of the executive/public civil servants, at all levels, Democratic decentralisation of government on the basis of the subsidiarity principle, The transparency and accountability of the military and police to elected government and the public, The capacity of the government to combat paramilitary groups, hoodlums and organised crime, The independence of the government from foreign intervention (except UN conventions and applicable international law), Government's 
Similarly, people's capacity to foster and use the institutions certainly varies with the social and economic conditions. Yet, the necessary minimum requirement is sufficient presence in the political terrain, capability to turn non-private issues into public matters, to enrol people in the efforts to promote them (i.e. to politicise issues and people), as well as to navigate the system. If this is not the case, the demos (the people) tend to be subordinated subjects rather than politically equal citizens.

The benefit of this conceptual exercise is that we may discuss the relative impact of dominant political tendencies in less sweeping terms: in what way does what politics affect what institutions and civic capacities? Neo-liberal as well as Muslim politicians may well respect the general aim of democracy but yet involve in fierce struggles as well as unholy alliances over the various instruments and capacities. Their positions on four questions are most important: (1) what constitute public affairs, (2) what constitute the demos, (3) what are the substance, performance and spread of the democratic institutions, and (4) how shall people be able to use them to control the public affairs? Let us begin by examining briefly the possible implications.

First, if only a few societal issues are considered to be public, there will be little left to take joint decisions about and few resources to share. Thus, democracy will be next to irrelevant. Typically, while Muslims tend to exclude a number of questions that people have in common from the public sphere, and rather leave them to the husband, family and religious leaders, neo-liberalism predicates that several questions of common concern are best governed through privatisation in favour of the market, corporate organisations, selfmanagement by 'responsible citizens' (for instance the villa-owners in a residential area) and the individuals themselves.

Second, if the people (demos) that is supposed to control the public affairs is defined on the basis of religious or similar identities (such as

independence from strong interest groups and capacity to eliminate corruption and abuse of power. (3) Democratically oriented civil society and direct participation: Freedom of the press, art and academic world, Public access to and the reflection of different views within media, art and the academic world, Citizens' participation in extensive independent civic associations, Transparency, accountability and democracy within civic organisations, All social groups' - including women's - extensive access to and participation in public life, Peoples' direct contact with the public services and servants. 
ethnic, clan, or birth place) rather than membership in a mutually defined public community, the political equality, which is fundamental to democracy, tends to be limited to special groups rather than to the population at large. It is true that only a few Muslims strive for an Islamic state, thus equating religious affiliation with citizenship. Usually, however, the many others who accept elements of pluralism still maintain that belief in some kind of an authorised God is a defining element of the demos and may be seen as basic sub-categories. All Indonesian citizens, for instance, are required to believe in one God (even the Hindus honouring many and the agnostics honouring none). Interestingly, moreover, similarly communitarian definitions of the demos regarding political representation seem to be quite possible to combine with neo-liberal positions in relation to the economy and certain individual freedoms, most recently, for instance, in the case of Hindu fundamentalist parties in India or the US policy in the Middle East and Afghanistan.

Third, within the framework of narrowly defined public affairs and the communitarian classifications of the demos, it is essential, of course, that at least the intrinsic means of democracy (that were presented earlier) are acknowledged. In-spite of the neo-liberal and Muslim views of public affairs and the demos, democracy may still develop and alter the constraints if the substance of the necessary instruments to promote democracy is not too narrow, if their performance and geographic scope is also not too poor, and if large parts of the population have significant capacity to promote and use them. Unfortunately, however, there are a number of additional problems in this respect. Free and fair elections as well as decentralisation, for instance, may be respected within Muslim as well as neo-liberal politics, but several of the other means of democracy tend to be weakened by the religion and market respectively. On the one hand, Muslim politics usually hollows out several of the inevitable freedoms such as 'equal citizenship', 'equal and secure access to justice', 'freedom of speech, assembly and association' and 'gender equality and emancipation'. On the other hand, neo-liberal preference for the strong actors on the markets limits the capacity of large sections of the population to actually promote and use the liberties. Further, while Muslim politics may promote measures against corruption, and neoliberal actors may foster the rule of the laws they have shaped, both 
tendencies neglect independent popular representation to promote politically equal control of public affairs.

Hence, several dimensions need to be considered. In a brief article like this, one way of capturing the prime tendencies is to focus on (a) the relevant dynamics between the major centres of power-the communitarian groups, the private business and market, and the state-, and (b) their relationship to the people.

Figure 1: Relations between the critical centres of power and their links to people

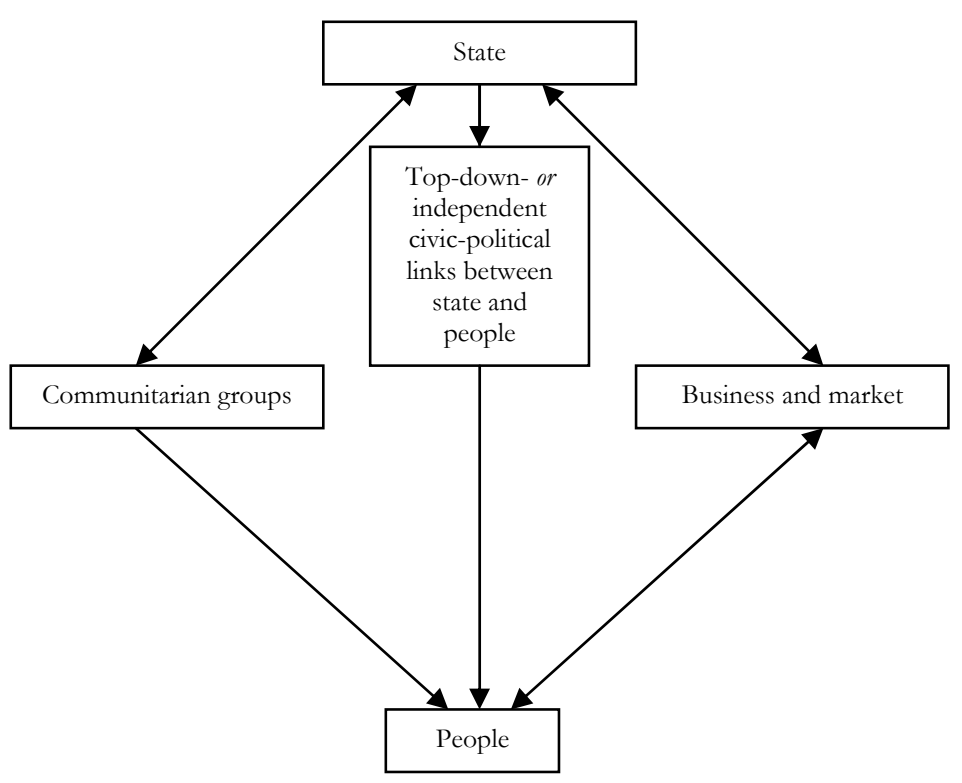

While Muslim as well as neo-liberal politicians often co-operate with state and government to gain favours and legitimacy, they also tend to agree on limiting the undemocratic statist or democratic public sphere in general and independent organisations connecting people and politics in particular. Their common alternatives to civic linkages are, on the one hand, communitarian mediation and patron-clientelism, and on the other, the invisible hands of the dominant actors on the market and civic self-management. 


\section{Historical Trends}

In view of this framework, what are the major aspects in the development of Muslim politics and democracy in Indonesia? Some historical aspects will be discussed first and the contemporary situation thereafter.

The traders who brought Islam with them to Indonesia did not use the same methods of state-backed repression, plundering and occupation as did the European colonizers in their pursuit for land and wealth. The foundation of Muslim politics rather seems to have been the combination of business and communitarian linkages, in negotiated agreement with various centres of political power.

The leading anti-colonial movements in the early to mid $20^{\text {th }}$ century combined Muslim faith and ethics with the ideals of the French revolution, the American declaration of freedom, and Marx' critique of capitalism and imperialism. Of course, some were politically more devoted Muslim than others. But the fundamental point is that all major political streams compromised their civic programmes and aspirations with communitarian mediation as well as direct charismaticpopulist links between politics and people. This was partially altered only by the communist led popular movements in the fifties, which tried to develop more independent civic connections between state and people.

Meanwhile neither Islam nor any other religion succeeded in dominating the Indonesian archipelago and become state builders. Religious extremists, whether Muslim or Christian, never won broad based popular support. This non-statist legacy was fundamental to Muslims and others who guarded the values of pluralism and tolerance, both as a way of handling conflicts and as an ideal. In fact, the broadminded groups fought against both Japanese fascists and European racists - attempting thus to build an embryonic democratic society and polity. It was perhaps overly idealistic, given their weak independent civic-political associations, but what else could they do?

Moreover, the fact remains that it was neither the followers of Islamic socio-religious reform movements nor communist worker and peasant movements who really undermined democracy towards the end of the fifties and early sixties, but rather some of the political leaders who subdued to European Cold War logic. There were three main tendencies. The socialists with prime roots among the emerging middle classes were unable to mobilise the masses and thus resorted to 
semi-authoritarian elitism. The broad nationalist and Muslim groups opted for combinations of communitarian and state based clientelism plus populism to gain followers. Tragically, finally, the communists, who had really managed to start building the first relatively independent mass based political movements also followed suit.

It is true that during the endgame in 1965-66, Muslim youths were mobilized by the military into well-organised youth groups to carry out the massacre of radical nationalists and communists. This had, however, less to do with religion than political and economic factors, combined with the historical - and still applied - method of privatising the means of violence through extreme political groupings, gangsters and militias.

Nor did Suharto receive much opposition from the Christian and liberal western part of the world during his thirty year long reign. Rather, Suharto was backed up by the West and cooperated with welleducated Christian technocrats, officers, and businessmen who were lacking broad and thus potentially threatening social or political bases.

Further, once having eliminated the relatively independent popular movements, Suharto could tap new substantial oil resources to subordinate communitarian and business groups and balance their mediation between state and people by way of direct stateauthoritarian linkages to semi-citizens who were thus turned subjects. It is true that towards the end of his rule Suharto tried to withstand critical students and popular discontent by flirting with Muslim intellectuals and their constituents. That said, naturally, the democracy movement that caused his demise in 1998 was anyway largely Muslim. For a brief period of time, many students were even able to build their own civic culture and catch people's imagination that this would be possible to scale up as an alternative democratic relation between people and state. But of course, lacking deep social roots and organisation, the dreams did not come true.

The violence that followed Suharto's step down from power was to a certain extent targeted by Muslims against Christians. But these conflicts were less about religion than the political and economic contradictions in Indonesia. As such, empirical research shows clearly that the main conflicts in the country have little to do with religion. People demand the same kinds of freedoms, rights, work, fair treatment and democratic representation as people do in other developing countries. The problem is that these conflicts and demands 
are not reflected in organized politics. In such instances, when facing a problem, one often turns to religious and other identity-based networks and tries and seeks special arrangements, thus also nourishing corruption.

\section{Contemporary Dynamics}

Of course it is troublesome that an increasing number of people now feel that the best way of fighting corruption and commercial moral disintegration is to support the Muslim brotherhood party PKS (Partai Keadilan Sejabtera/Prosperous Justice Party) and similar groups. Currently, the PKS and other parties (which do not want to lose out by being less devoted) are enforcing religious laws on the local level and trying to gather political majority in favour of a national antipornography bill, which in essence does not turn against dirty men but women who at least try to dress and move about as they wish. It is in such instances that the pluralism and tolerance that turned many Muslims into pioneering democrats during the liberation struggle, in the early fifties and in fighting Suharto is further undermined.

The current dynamics is worrying. I am primarily drawing on the previous case studies and data collected by Demos among senior reflective pro-democracy activists around the country, ${ }^{2}$ the opinion polls, reports and discourse in national media (including Tempo and Jakarta Post), the monitoring by various NGOs of popular discontent, and the particularly important research on the increasingly localised politics. ${ }^{3}$ When reading the empirical evidence in view of the analytical framework of this article, the crucial political dynamics stand out as a triangular one between dominant actors with powers and interests related to (a) the 'decapitated' state at the top, thus being weakened, fragmented and localised, (b) the increasingly strong religious and other communal forces, and (c) the equally reinforced interests related to private business and market, in each of the fundamental corners. Nobody is rooted in 'their own' corner only but there are horse-trading in all directions. The unholy alliance is the strongest - between, on the

\footnotetext{
2 See Stanley Prasetyo, et. al., Indonesia's Post-Soeharto Democracy Movement (Jakarta: Demos, 2003); Cf. Priyono, et. al. (eds.), Making Democracy Meaningful: Problems and Options in Indonesia (Forthcoming) (Jakarta and Singapore: Demos and ISEAS, 2007); additional results on http://www.demos.or.id.

3 Including the results from the pioneering research programme 'Renegotiating Boundaries', see http://www.kitlv.nl/renegotiating.html.
} 
one hand, the religious and other communitarian groups, who reduce the public sphere in favour of for instance religiously prescribed moral rules and values, and, on the other, the pro-business and market groups that privatise public resources. The loudspeakers on top of the Mosques and in the shopping malls do not speak the same language, but the high volume is the same. Meanwhile, both camps retain of course their increasingly informal control of patches of the 'decapitated' state.

Worst: in-spite of attempts at building democracy, increasingly many relations between state and people are being mediated by these forces. The previously matching authoritarian top-down linkages under Suharto have disintegrated. The previous predominance of clientelism and populism is back in full swing. However, personality-oriented populism under President Susilo Bambang Yudoyono and a large number of equally directly elected governors, mayors and regents is much more conservative and money-driven than the classical rural romantic brand of founding father Sukarno. Most importantly: nothing is there to substitute for the comparatively modern communist led popular movements. The independent civic-political links between state and people remain critically weak.

Yet, the reason for this democratic deficit has less to do with Islamic religion than with the decades of authoritarianism, the crusades in Iraq, the disrespect of Muslims in, for instance, a certain Danish newspaper, and the fact that Indonesian secular democrats have not been successful in building a well functioning political party or block with broad based support instead of complaining about dirty politics and withdrawing into a myriad of civil society organizations without much coordination or power.

The empirical evidence in Demos' national expert survey (in cooperation with the democracy movement and the University of Oslo) is overwhelming. Eight hundred well reputed local activists in Indonesia's thirty two provinces have answered three hundred and thirty questions about the problems and conditions for democracy. The main problem, they say, is that the existence of a number of freedoms and a broad civil society has not been able to promote and secure people's basic needs, a well functioning legal system, nor a representative and responsible leadership. This implies that democratic elections have not in fact led to the interests and conflicts of ordinary people being represented. It also implies that the important battle 
against corruption, nepotism, and centralism has weakened the state's resources and capacity under a neo-liberalist regime rather than strengthening democratic public capacities, meaning that clientelism and corruption continues to operate. The dominant elite have on the one hand become less exclusive and adapted to the rules of the democratic game, but are on the other hand monopolising and abusing the nominally democratic institutions. The pro-democratic forces are still important but politically marginalised as individuals in elitist parties or as activists in civil society organisations without much coordination and a social basis among the people at large.

In short, there are no visible real alternatives. Democracy is squeezed from all corners. The powerful groups tend to reinforce the triangular alliances and little can be done by people themselves. The independent links between state and people (for instance through popular controlled parties and interest organisations) are very weak. Most relations between the state and the people are mediated through the communitarian groups and the business and market, thus cementing clientelism and corruption. Hence, the problem is not religion and Islam as such but that democratisation has run aground for a number of other reasons. The real challenge is to develop more independent means of political representation. So what can be done?

\section{Democratic Options}

The Aceh peace agreement is an illustration for what is possible. If Indonesian democracy is widened at the local level, fighting in the battlefield may be transferred onto the political arena and foster development. Demos' survey indicates that the major task in the country at large is to build popularly rooted and representative civic-political organisations.

However, pro-democrats face grim realities. The same survey shows very clearly that most of them remain just as socially floating in the public discourse, without firm roots among the people at large, as the masses were meant to be politically floating in the villages under Suharto. Meanwhile, the neo-liberal hollowing out of public resources and governance sustains incorporation of people into politics through clientelism and populism. With less public resources, people need even more fixers, patrons and communitarian 'solidarity'. Thus prodemocratic promotion of public solutions to people's problems and programmatic platforms for pro-poor policies are considered fine but unrealistic. Nobody wins an election without promising instead special 
favours and patronage. Besides, most civic organisations are miserable vote-catchers, resorting instead to pressure politics and lobbyism.

As a consequence, self-help programmes gain importance including some civic but primarily communitarian and most frequently Muslim-oriented. Many of them are vital to the people affected, but in the process well endowed and vulnerable people are separated, even the poor are fragmented in different projects and communities, and it is difficult to reconcile the various efforts with the principle of political equality and basic public rights. Perhaps it is possible instead to seek inspiration from comparative studies suggesting that struggle for democratic regulations may serve as a realistic and unifying supplementary framework; a framework sustaining principles of universal social and economic rights and bringing self-management in line with democratic political equality and impartiality without engaging in unrealistic demands for full public ownership and control. Yet, this is easier said than done. Participatory budgeting or decentralised people's planning, for instance, is not possible to introduce by design only but calls for political change and facilitation. ${ }^{4}$ Moreover, as Mushtaq Khan convincingly reminds us, there must be some resources and capacities to share for a reasonably meaningful democracy to make sense. ${ }^{5}$ If not, Muslim and other forms of communitarianism and clientelism will flourish as much as the dominant forces on the market.

How does one generate more public resources? Post-colonial countries like Indonesia continue to suffer from uneven development. In other words, the state may still be big but it is not strong. And the advanced sectors of capital and middle classes are not always progressive but benefit from the underdeveloped poor sectors and from primitive accumulation through coercion and dominance, in symbiotic relation with state- and communitarian based groups. These are the roots of the dominant actors that distort Indonesia's social and economic development and monopolise its fledgling democracy.

What can be done? The established strategies to alter the stalemate are democratically unviable. Previous attempts at state-led 'national democratic development' like during Sukarno undermined democracy

\footnotetext{
4 See, John Harriss et. al. (eds.), Politicising Democracy, The New Local Politics of Democratisation (Houndmills, Basingstoke: Palgrave, 2004).

${ }^{5}$ Mushtaq H Khan, "Markets, States and Democracy: Patron-Client Networks and the Case for Democracy in Developing Countries", Democratization, Vol. 12 No. 5 (December 2005), pp. 707-724.
} 
and have been invalidated by capitalist globalisation. The crafting of institutions during the 'third wave of democracy' to turn powerful actors into democrats - including the efforts by international experts and 'moderate' reform oriented sections of the elite after Suharto ${ }^{6}-$ has proved as insufficient in Indonesia as elsewhere in the South and the former Eastern Block. The powerful actors avoid or hijack the new rules of the game. Efforts to give priority instead to the shaping of a liberal European-like rechtsstaat by way of 'good governance reforms', ahead of further democratisation, as frequently argued by the IMF and World Bank, ${ }^{7}$ suffer from the weakness of liberal oriented bourgeois and middle classes. Hence is thus likely to call for more or less authoritarian solutions, as most recently in the royal-military and urban middle class coup in Thailand. Neither is there a reasonably democratic developmental state at hand that can generate more public resources through pro-business policies. ${ }^{8}$ Worst: the pro-democracy activists have almost nothing to offer in terms of a realistic alternative. The recent admiration for Latin American populist-nationalists Chavez and Morales has little relevance beyond struggle against international finance capital and foreign dominance of natural resources. The crucial issues of how to fight and build an alternative to the symbiosis between state, communitarianism and private business, increase economic growth for more public resources and demonopolise democracy are almost as neglected as during the hegemony of the radical nationalists in the late fifties and early sixties. ${ }^{9}$

The major popular alternative top these problematic roadmaps is Muslim aspirations at a value-based welfare state. The general thesis (from for instance Turkey, Egypt, Iran and Malaysia) seems to be that

\footnotetext{
${ }^{6}$ R. William Liddle (eds.), Crafting Indonesian Democracy (Jakarta: PPW-LIPI, Ford Foundation and Mizan Pustaka, 2001).

7 See http://www.worldbank.org./wbi/governance. For a blunt introduction in the Indonesian discourse, see Guido Tabellini's "Economic Reforms Proceed Democracy", Jakarta Post, 15 September, 2005.

8 A major weakness in the former mentioned article by Khan. See Khan, "Markets, States and Democracy".

${ }^{9}$ For an analysis of the problems of the Indonesian radicals in this respect, see Olle Törnquist, Dilemmas of Third World Communism: The Destruction of the PKI in Indonesia (London: Zed, 1984), and for comparisons with India, see Idem, What's Wrong with Marxism? Vo.1: On Capitalists and State in India and Indonesia. Vol. 2: On Peasants and Workers in India and Indonesia (New Delhi: Manohar, 1989 \& 1991).
} 
the problems of development and democracy are due primarily to insufficient moral codes and values in local communities and families. This drawback, it is argued, paves the way for individualistic greediness, corruption and exploitative and western dominated neoliberal capitalism. Consequently, the public democratic sphere with extensive liberal freedoms should be reduced in favour of religiously governed ethic codes, community- and family relations. Beyond these restrictions, however, several of the other elements of democracy may apply, including free and fair elections. This kind of privatisation is better, it is argued, than the neo-liberal and exploitative one. For instance, there are social-welfare policies with roots in community contribution and redistribution (the internationally best know case of which is probably Hamas), co-operatives and the interest free Islamic banking system.

The way that this thinking is gaining quick ground in Indonesia is obviously related to the failure of the other perspectives to make democracy meaningful for ordinary people after the Asian economic crisis and the fall of the Suharto regime - supplemented again, of course, by the Western crusades in the Middle East.

From a democratic point of view, the main problem, in addition to the serious reductions of the public sphere and illiberal measures, that most of the comparatively impressive anti-corruption and social welfare measures are (as already pointed out) meditated between state and people through communities and patron-client relations rather than direct and through impartial institutions facilitated by civic organisation. This breeds rivalries, undermines the anti-corruption efforts and reduces the pro-democratic potential. There is also to my knowledge no strategy for how to break away from the unholy alliances between the communitarian ideals and related strongmen in relation to both the state and private business at central and local levels. This is not a new problem, but probably the basic reason for why the two major groups of semi-democratic Muslims - one related to then president Habibie and the other to the later president Wahid never managed to form the real alternatives to Suharto that they were striving for. And there are no clear signs of change in this respect.

In brief, therefore, efforts at fostering representation of potentially powerful agents in favour of an alternative development project and thus more public resources still seem to rest with the civic prodemocrats. If not, meaningful democracy is likely to be a lost case. To 
my knowledge, the historical and present attempts in contexts like Indonesia where international economic competition can not be avoided, seem to focus on the promotion of representation of powerful groups that would be in favour of limited growth oriented pacts between sections of labour and capital; sections which in turn may develop common interest in public resources for general public welfare policies and the need for democracy to facilitate such agreements. Unfortunately, however, as compared to countries such as South Africa and Brazil where these problems are on top of the agenda, there seem to be little interest in Indonesia. Hence, the playing field is once again left open for the unholy alliance between Muslim communitarianism and neo-liberalism.

\section{Conclusion}

In short, the Indonesian lesson is obvious. Muslim democrats liberated the country and re-introduced the world's third largest democracy. On the one hand it is true that this is not without problems, currently including the local introduction of religious rather than democratic laws and the basic ideas behind the anti-pornography bill. On the other hand it is also true that the Muslim semi-democrats are politically quite pragmatic, in spite of occasional declarations. Just as in Turkey they may adjust to the wider comprehensive sets of democratic principles and instruments, including with regard to citizenship rights and political equality, both with regard to the input as well as output side of democracy. ${ }^{10}$ However, this adjustment seem to rest with to the independent development of a sufficiently strong and meaningful democracy that may discipline the communitarian tendencies - just as, conversely, the worrying reduction of the public sphere and clientelistic brand of social welfare have been related to the poor development of democracy.

But when we worry less about Islam's negative impact and more about how the basic hindrances against meaningful democracy may be overcome by building politically equal citizenship and representative

\footnotetext{
${ }^{10}$ Martin van Bruinessen, "Post-Soeharto Muslim Engagements with Civil Society and Democratization", in Samuel Hanneman \& Henk Schulte Nordholt (eds.), Indonesia in Transition, Rethinking 'Civil Society', 'Region' and 'Crisis' (Yogyakarta: Pustaka Pelajar, 2004). Cf. Wajidi, Farid (2004). "NU Youth and the Making of Civil Society: Notes from the Field". in Samuel Hanneman \& Henk Schulte Nordholt (eds.), Indonesia in Transition, Rethinking 'Civil' Society, 'Region' and 'Crisis'.
} 
links between people and politics - so that democratic regulations may contain communitarianism, turn self-management more politically equal, and foster growth and public welfare oriented growth - the worrying connections between politics and religion will be far less significant. The basic changes that seem to be needed in order to transform the democratically destructive dynamics into a more productive are indicated in the figure below.

Figure 2: Transforming the democratically destructive dynamics?

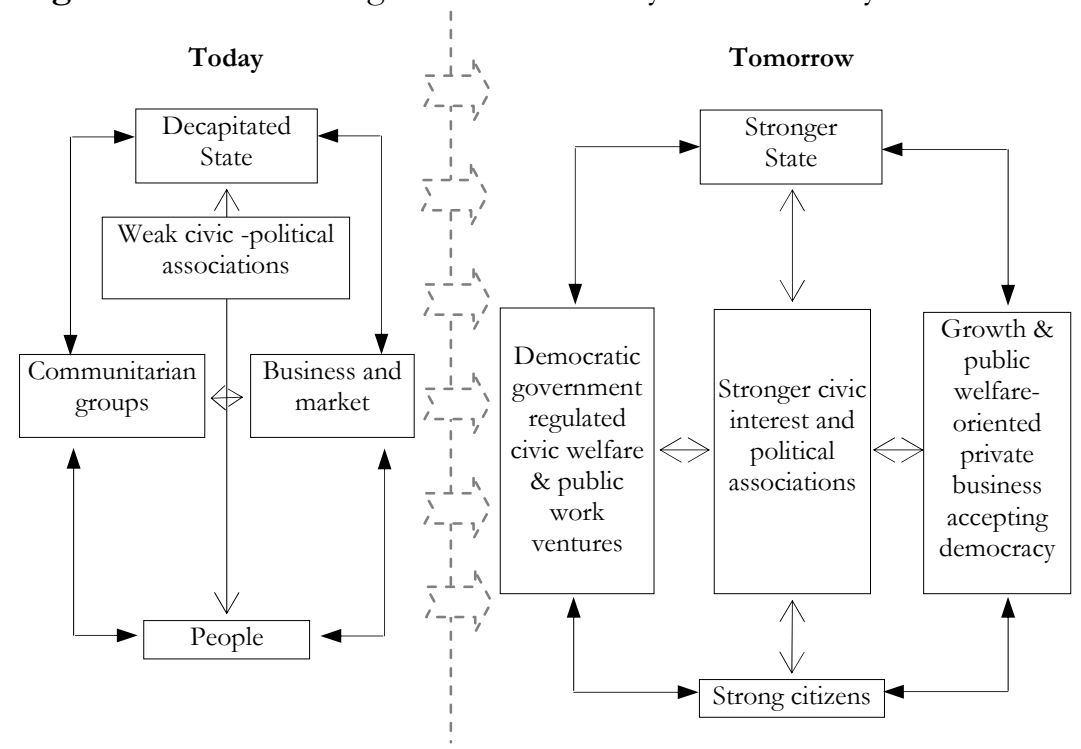

\section{Bibliography}

\section{Books and Articles}

Beetham, David, et. al. International IDEA Handbook on Democracy Assessment. The Hague: Kluwer Law International, 2002.

Harriss, John, et. al. (eds.). Politicising Democracy, The New Local Politics of Democratisation. Houndmills, Basingstoke: Palgrave, 2004.

Khan, Mushtaq H. "Markets, States and Democracy: Patron-Client Networks and the Case for Democracy in Developing 
Countries." Democratization, Vol. 12, No. 5, December 2005: pp. 707-724.

Liddle, William R. (ed.). Crafting Indonesian Democracy. Jakarta: PPWLIPI, Ford Foundation and Mizan Pustaka, 2001.

Prasetyo, Stanley, et. al. Indonesia's Post-Soeharto Democracy Movement, Jakarta: Demos, 2003.

Priyono, A.E, et. al. (eds.). Making Democracy Meaningful, Problems and Options in Indonesia (Forthcoming). Jakarta and Singapore: Demos and ISEAS, 2007.

Tabellini, Guido, "Economic Reforms Proceed Democracy". Jakarta Post. September 15, 2005.

Törnquist, Olle. Dilemmas of Third World Communism: The Destruction of the PKI in Indonesia. London: Zed, 1984.

--------. What's Wrong with Marxism? Vo.1: On Capitalists and State in India and Indonesia. Vol. 2: On Peasants and Workers in India and Indonesia. New Delhi: Manohar, 1989 \& 1991.

------. "Assessing Democracy from Below: A Framework and Indonesian Pilot Study". Democratization, Vol. 13, No. 2, April 2006, pp. 227-255.

van Bruinessen, Martin. "Post-Soeharto Muslim Engagements with Civil Society and Democratization" in Hanneman Samuel \& Henk Schulte Nordholt (eds.). Indonesia in Transition, Retbinking 'Civil Society', 'Region' and 'Crisis'. Yogyakarta: Pustaka Pelajar, 2004.

Wajidi, Farid. "NU Youth and the Making of Civil Society: Notes from the Field", in Hanneman Samuel \& Henk Schulte Nordholt (eds.). Indonesia in Transition, Retbinking 'Civil Society', 'Region' and 'Crisis'.

\section{Electronic Sources}

http://www.demos.or.id

http://www.kitlv.nl/renegotiating.html

http://www.worldbank.org./wbi/governance 